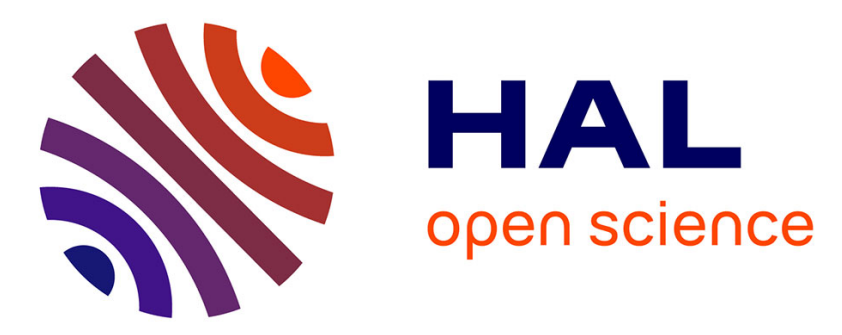

\title{
Seasonal changes in the biochemical composition of the edible sea urchin Paracentrotus lividus (Echinodermata: Echinoidea) in a lagoonal environment
}

Catherine Fernandez

\section{- To cite this version: \\ Catherine Fernandez. Seasonal changes in the biochemical composition of the edible sea urchin Para- centrotus lividus (Echinodermata: Echinoidea) in a lagoonal environment. Marine Ecology, 1998, 19 (1), pp.1-11. hal-01768828}

\section{HAL Id: hal-01768828 \\ https://hal.science/hal-01768828}

Submitted on 17 Apr 2018

HAL is a multi-disciplinary open access archive for the deposit and dissemination of scientific research documents, whether they are published or not. The documents may come from teaching and research institutions in France or abroad, or from public or private research centers.
L'archive ouverte pluridisciplinaire HAL, est destinée au dépôt et à la diffusion de documents scientifiques de niveau recherche, publiés ou non, émanant des établissements d'enseignement et de recherche français ou étrangers, des laboratoires publics ou privés. 


\title{
Seasonal Changes in the Biochemical Composition of the Edible Sea Urchin Paracentrotus lividus (Echinodermata: Echinoidea) in a Lagoonal Environment
}

\author{
C. FERNANISI:Z. \\ EyEL, Université de Corse, BP 52, F-20 250 Corte, France and \\ LBMEB. Université Aix-Marseille II. Faculté des sciences de Luminy, \\ F-13288 Marseille cedex 9. France. \\ With 4 ligures
}

Key words: Echinoid, Parachnorus liridus, biochemical composition, protein, carbohydrate, lipid, energy, seasonal variation, coastal lagoon.

\begin{abstract}
Monthly soluble and insoluble protcin. carbohydrate, lipid and ash levels and energetic content were medsured in tissues of Paracentrotus /ividus adults living in a lagoonal environment over a l-year period to increase our underslanding of resource allocation to the different tissues. The biochemical composition of $P$. licidus individuals in this environment is similar to that observed in other environments. The gonad and gut contained a high level of proteins (soluble or insoluble), a lesser amount of lipids and. finally, a low level of carbohydrates. The main component of the test was ash, followed by protein levels. The lipid and carbohydrate levels in the test were very low, Seasonal variability in the biochemical composition of the different body parts was observed. In the gonad, an increase in the lovel of lipids was recorded concomitant to an increase in gonad weight. The lipids and carbohydrates. after an initial increase, decreased with the maturation of the gonad. The biochemical varjations observed in the gut seem to be linked to both the reproductive eycle and the sea urchin"s Irophic activity. Variability in the test was low and irregular for all of the observed biochemical components. As P. lividus is an important member of the benthic community in the Urbinu lagoon. this echinoid represents an important store of materials and energy within this lagoonal environment.
\end{abstract}

\section{Problem}

The biochemical composition of the Echinodermata has been studied in a number of marine species inhabiting both coastal or deep waters and originating from tropical, temperate or polar environments (GIESE, 1996a,b; LAWrf.NCE, 1973; SIBUet \& Lamrfice, 1981; Lawrince \& Guille, 1982; Mc Clintock \& Pearse, 1987; MCCLiNTock et al., 1990a,b). Insight on biochemical composition is important at the tissue, organism and population levels. These studies provide information at several levels: they can explain the nature and role of the tissues and cells which compose them (GIESE, 1966a,b; LAWRENCE \& GUILLE, 1982) and they can be used to calculate energy allocation in body components or the energetic biomass of populations (LAWRENCE \& KAFrI, 1979; MCCLINTOCK ef al., 1990a). They can also

L. S. Copyright Clearance Center Code Statement: 0173-9565/98/1901-0001\$14.00/0 
be used to define nutritive requirements (applicable in the development of artificial diets) (FLoRETo et al., 1996). Sea urchins are of ten the dominant herbivore in many sublittoral communities and are frequently regarded as determinants of community structure in marine macrophyte habitats (MILLER \& MAN, 1973; LAWRENCE, 1975; LAWRENCE \& SAMMARCo, 1982). They play a particularly important role in the transfer of energy between benthic and pelagic environments (FENAUX et al., 1977). Paracentrotus lividus (LAMARCK) plays such a role in the Mediterranean Sea (VERLAQUE, 1987). In addition, this species is actively fished in a number of regions and is the object of budding aquaculture activity (LEDiREAC'H, 1987; LEGALL \& Bucaille, 1987; LeGall, 1989; Fernandez \& Caltagirone, 1994; Grosjean \& JANGOUX, 1994; Fernandez et al., 1995). The aim of the present study was to examine seasonal variability in the biochemical and energetic composition of sea urchin tissues from a lagoon environment and to link these variations to the organisms' feeding and reproductive cycles (Fernandez \& BoudouresQue, 1997).

\section{Material and Methods}

Specimens of $P$. lividus were collected from a scagrass site situated in the Urbinu lagoon. This lagoon is located in Corsica (France), on the coast of the eastern plain of the island ( $42^{\prime} 03^{\prime} \mathrm{N}$; $9^{\prime} 28^{\prime}$ E). The seagrass bed is characterized by a sandy bottom colonized by the seagrass Cymodocea nodosa UCRIA (AsfIERSON). This dense bed (750 shoots $\mathrm{m}^{-2}$ ) provides an abundant supply of food. C. nodosa is considered to be a preferred food source for $P$. lividus (TRAER, 1980). At this site, the sea urchin population density is low $\left(0.7 \pm 0.4\right.$ indiv. $\mathrm{m}^{-2}$ ) and composed mainly of adults (FERNANDEZ. 1990, 1996; Fernandez \& Boudourtsque, 1997). Ten sea urchins $41-50 \mathrm{~mm}$ in size, were sampled monthly from June 1991 to June 1992 by SCUBA diving. All individuals were dissected into the following body components: test (with spines), gonad, gut and gut contents. Each compartment was drained on filter paper and weighed to the nearest $0.1 \mathrm{mg}$ (wet weight). For each compartment, half was weighed (wet weight) and dried at $70^{\circ} \mathrm{C}$ to constant weight for estimation of water content (difference between wet and dry weight) (for gut contents, the whole amount was dried). The gonad and repletion indices were then calculated. The relationship used was: $\mathrm{CI}\left[\mathrm{mg}^{\cdot} \mathrm{cm}^{-3}\right]=\mathrm{DWC}+\mathrm{d}^{-3}$ where CI (Component Index) is the ratio between the dry weight of the component ( $D W C$ ) expressed in $\mathrm{mg}$ and the test diameter cubed $\left(\mathrm{d}^{3}\right)$ expressed in $\mathrm{cm}^{3}$ [this relationship is derived from the index of repletion in NÉDfíteC (1983)]. The results of these indices have been discussed previously in Fernandez. \& Boudouresoue (1997).

The other half part of each tissue type was homogenized with an Ultra turax and the level of soluble proteins, carbohydrates and lipids was determined using the techniques of LOWRY (1951), DuBois et al. (1956) and BARNES \& BLACK TOCK (1973), respectively. Water content was determined by placing tissues in an oven at $70^{\circ} \mathrm{C}$ until a constant weight was obtained. Ash was measured by placing the dried tissues in a muffle furnace at $500^{\circ} \mathrm{C}$ for $4 \mathrm{~h}$. Insoluble protein levels were estimated by subtraction as described by LAWRENCF \& KAFRI (1979) (although this method is generally accepted, it may be somewhat problematic for mature testes in which nucleic acids, rather than insoluble proteins, may contribute significantly to the composition of the tissue). The energetic values of tissues werc calculated by multiplying the level of each organic constituent by its energy equivalent (BRODY, 1945) and by adding the energetic levels of all the constituents. Data have been processed by one-way analysis of variance (one-way ANOVA) followed by tests of TUKEY or KRUSKAL-Wallis test. Previously, normality and homoscedasticity were verified by KOLMOGOROV-SMIRNOV and BARTIETT tests, respectively (ZAR, 1984). The software Stratgraphies plus (v. 1.4) for Windows was used.

\section{Results}

The biochemical composition of the gonad and gut of Paracentrotus lividus exhibited seasonal variations (Figs 1 and 2). For the gonads, statistical analysis of the 

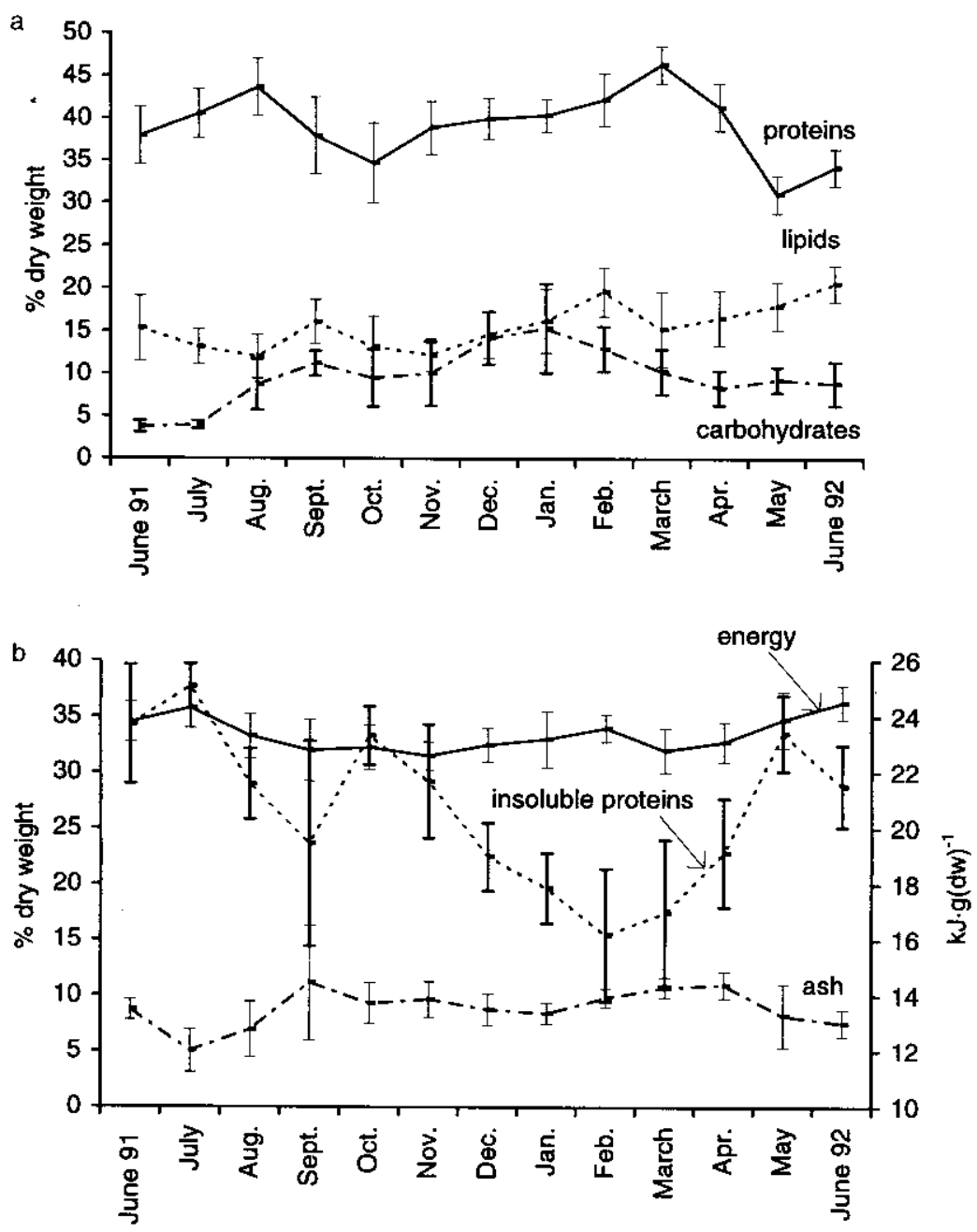

Fig. 1. Mean seasonal changes in energy [expressed in $\mathrm{kJ} \cdot \mathrm{g}$ (dry weight $)^{-1}$ ] and biochemical composition (\% dry weight) $( \pm \mathrm{CI}, \mathrm{n}=10)$ for the gonads of Paracentrotus lividus living in seagrass beds. a: soluble protein, lipid and carbohydrate levels. b: insoluble proteins, ash level and energy content.

temporal variations of the different nutrient components revealed that the level of soluble protein increased significantly from October 1991 to March 1992, followed by a significant decrease between April and June 1992 (one-way ANOVA, F =8.42, $P<0.0001$ ) (Fig. 1a). This evolution of the gonadal proteins followed closely the progression of the gonadal index (Fig. 3). A significant correlation exists between these two parameters throughout the year-long study period $(r=0.83$, $r$ significance test, $\mathrm{P}<0.05$ ). As for the carbohydrate levels, a significant increase was observed between July 1991 and January 1992, followed by low values from April to June 1992 (one-way ANOVA, $\mathrm{F}=7.37, \mathrm{P}<0.0001$ ), with the decrease being initiated in January (Fig. 1a). The relationship between these carbohydrate levels 

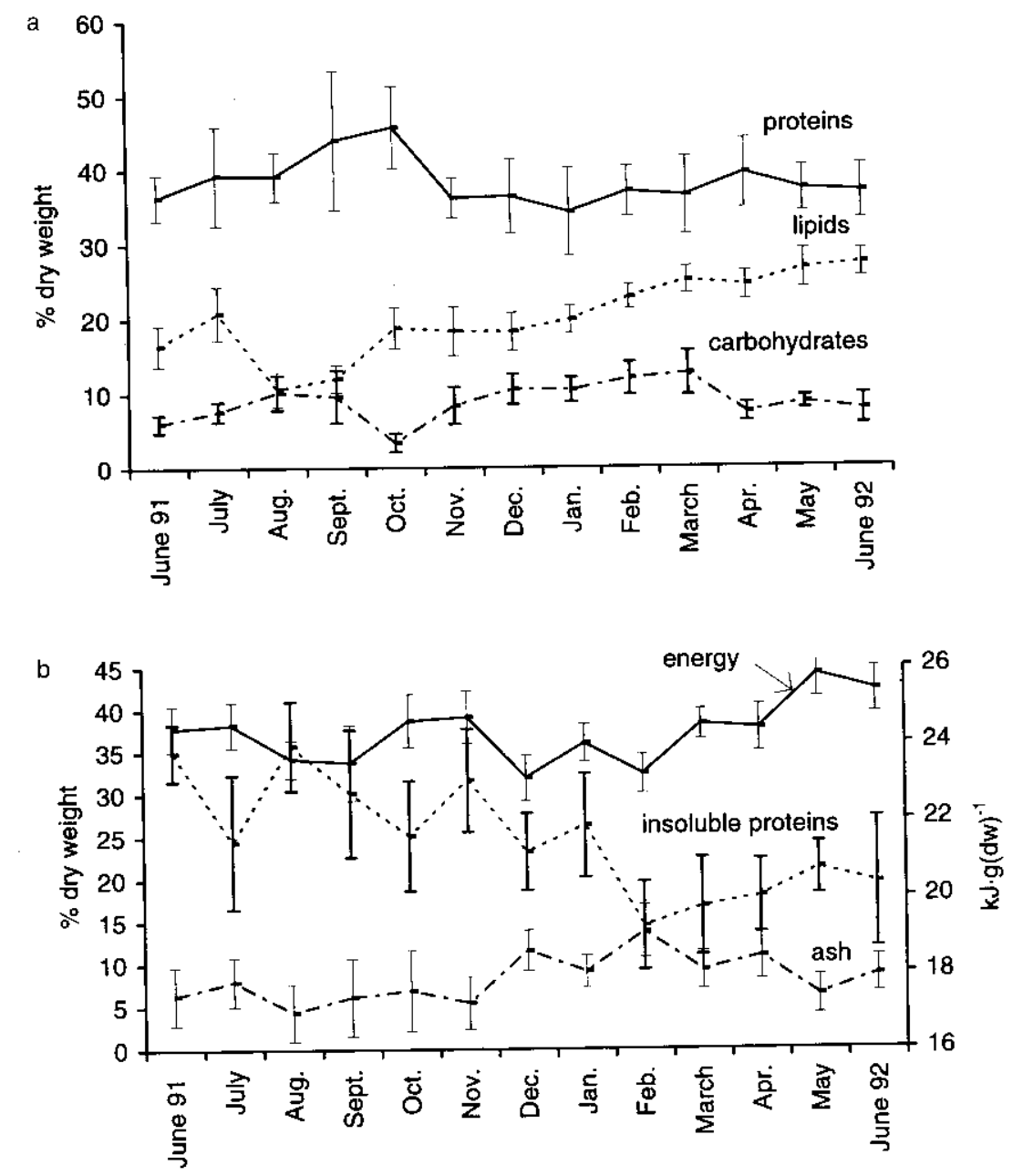

Fig. 2. Mean sedsonal changes in energy [expressed in $\mathrm{kJ} \cdot \mathrm{g}$ (dry weight) '] and biochemical composition Fig. 2. Mean seasonal changes in energy lexpressed in $\mathrm{kJ} \cdot \mathrm{g}$ (dry weight) and biochenical composition protein. lipid and carbohydrate leveis. b: insoluble proteins, ash level and energy contcnt.

and the gonadal index is less evident than for the proteins. Nevertheless, the sugar levels apparently increased during gonad development and subsequently decreased during the last month of gonadal growth. Following a short period during which lipid levels remained constant. lipids increased from November 1991 to February 1992, decreased in March, and then remained at the same level from April to June 1992 (KRUSKal-Wallis test, $F=37.3, P<0.0001$ ). In addition, lipids are accumulated after the fall spawn and then drop at the beginning of the gonad index's diminution. Ash content slightly increased between July 1991 and March 1992 (one-way ANOVA, $\mathrm{F}=3.1, \mathrm{P}<0.05$; Tukey test, $\mathrm{P}<0.05$ ) (Fig. la). The energy content of the gonads was lower in autumn and winter (September to December) than in spring and summer (May to August) (one-way ANOVA, 


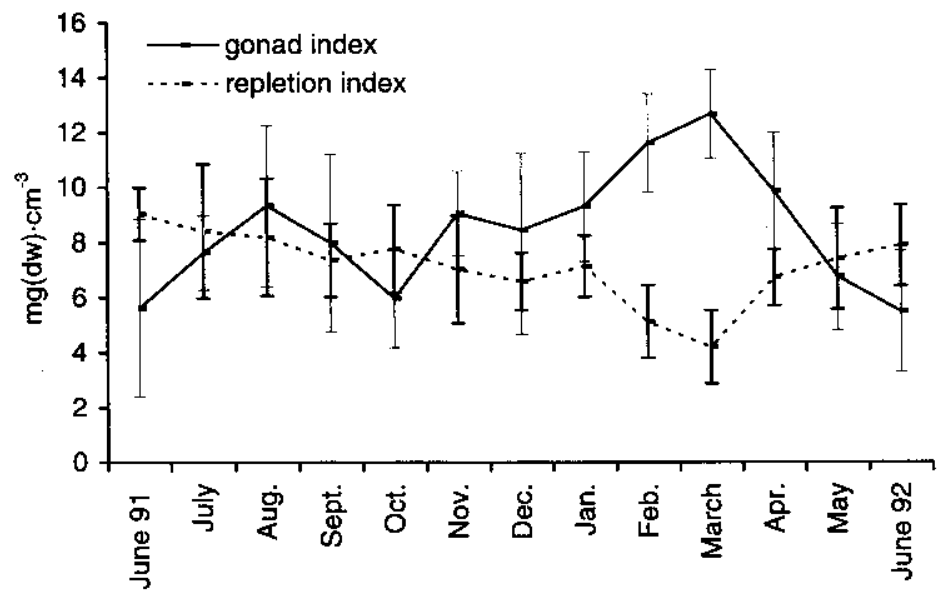

Fig. 3. Annuat cyche for the gonads and repletion indices of Paracentrotus lizidus living in scagrass beds from Jute 199] to June 1992 (from Fuknanijf. \& BoudourtsquF., 1997).

$\mathrm{F}=2.3, \mathrm{P}<0.05$; Tukey test, $\mathrm{P}<0.05$ ) (Fig. Ib). Finally, the lipid levels were higher in the femalc gonad than in the male testes (Student's t-test, $\mathrm{P}<0.05$ ).

The level of organic matter in the gut also exhibited seasonal variability (Fig. 2). Statistical analysis, however, revealed that the variations in soluble protein levels are not significant (KRUSKAL-W carbohydrate levels in the gut is more evident; sugar levels increased during the summer (from June to August) and then decreased to minimum values in October 1991. A second increase in carbohydrate levels occurred from October to March 1992, followed by a decrease in April, after which levels remained stable until June 1992 (one-way ANOVA, $\mathrm{F}=7.03, \mathrm{P}<0.0001$; Tukey test, $\mathrm{P}<0.05$ ) (Fig. 2a). The variation in lipid levels throughout the study period was less obvious, with a decrease during the summer (Junc to August 1991), a slow increase from August to March 1992. followed by a stabilization of levels through to June 1992 (oneway ANOVA, $\mathrm{F}=21.86, \mathrm{P}<0.0001$; Tukey test, $\mathrm{P}<0.05$ ). The energy content of the gut varied during the year but these variations were erratic (one-way ANOVA, $\mathrm{F}=8.8, \mathrm{P}<0.001$; Tukey test, $\mathrm{P}<0.05$ ) (Fig. 2b).

Seasonal variability of the biochemical components in the test throughout the 1-year sampling period was fairly low (Fig. 4). The variations in insoluble protein and ash levels were not significant (one-way ANOVA, $F=0.54$ and 0.63 , respectively; $\mathrm{P}>0.05$ ). Conversely, soluble protein, carbohydrate and lipid levels varied significantly (one-way ANOVA for the proteins and lipids, $F=2.79$ and 16.25 respectively, $\mathrm{P}<0.05$ ) (KRUSKAL-WALLIS test for the carbohydrates, $t=74.08$; $\mathrm{P}<0.05$ ). The protein levels ranged from $3.4 \%$ in August to $2.2 \%$ in December. In a generalized fashion, protein levels decreased from the summer months to December and then increased until the spring. The carbohydrates followed a more erratic temporal evolution, with levels ranging from $0.2 \%$ in October to $0.3 \%$ in March. Finally, the lipid levels ranged from $0.2 \%$ in May to $0.5 \%$ in March. 
a
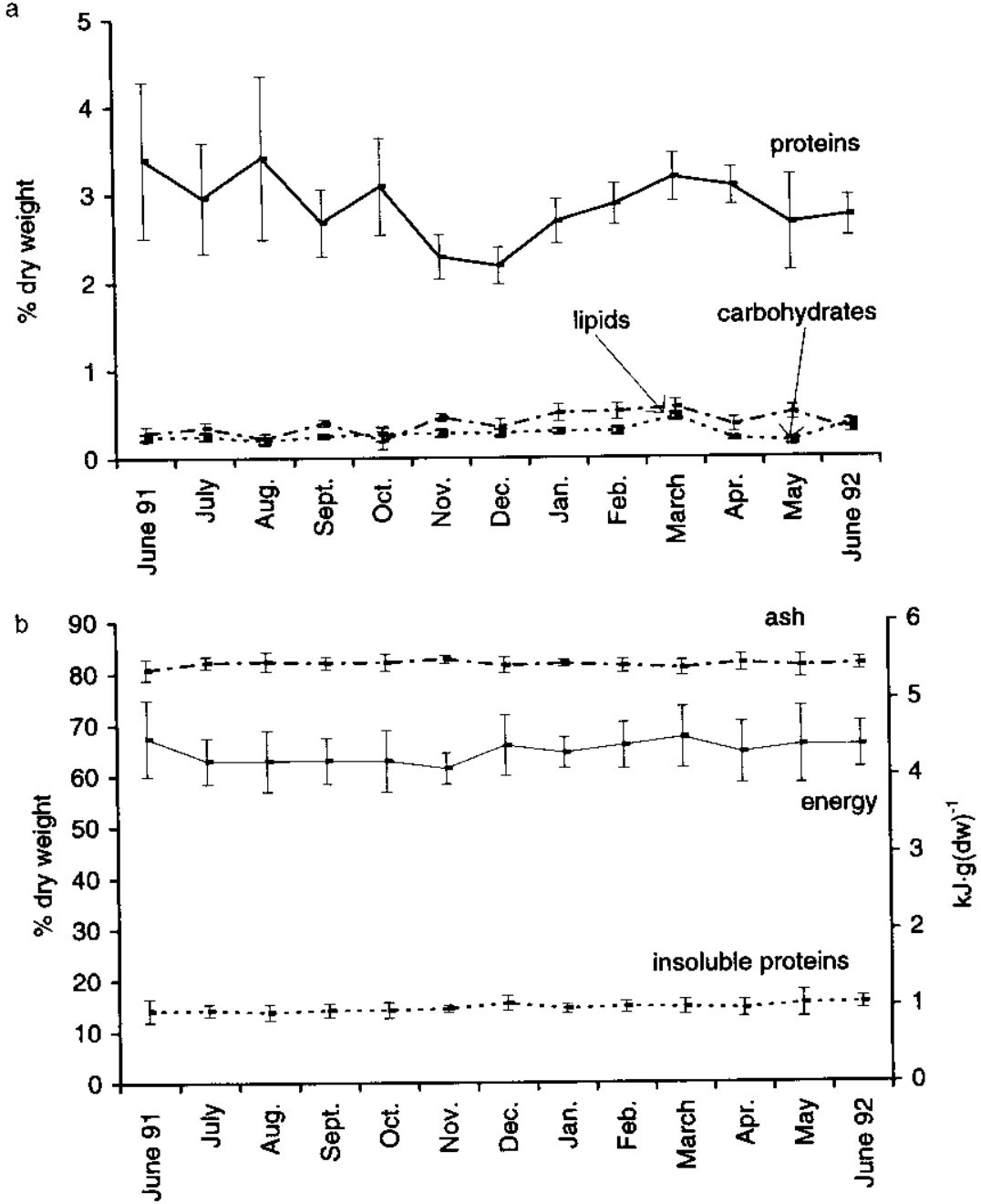

Fig. 4. Mean seasonal changes in energy [expressed in $\mathrm{kJ} \cdot \mathrm{g}$ (dry weight) $\left.{ }^{\prime}\right]$ and biochemical composition ( $\%$ dry weight) $( \pm \mathrm{CI}, \mathrm{n}=10$ ) for the test of Paracentrotus lividus living in seagrass beds. a: soluble protein, lipid and carbohydrate levels. b: insoluble proteins, ash level and energy content.

\section{Discussion}

The biochemical composition of the gonad and gut of $P$. lividus living in a lagoon environment is similar to that observed in various other temperate, tropical and polar Echinoidea species (GEESE, 1966a,b; LAWRENCE \& GUILle, 1982; MCCLINTOCK \& PEARSE, 1987; LAWRENCE \& BYrNe, 1994). These two organs contain high levels of protein (both soluble and insoluble). Lipids are also relatively abundant while carbohydrate levels are low. Based on results gleaned from the literature, the Mediterranean sea urchin Arbacia lixula (Linnaeus) is the species whose study generates data the closest to those presented here (FENAux et al., 1975, 1977). 
Such similarities in the distribution of biochemical components are due to the organization of the various organs, which is similar in all the Echinoidea, regardless of species and geographical location (LAWRENCE \& GUILlE, 1982; MCClintock \& Pearse, 1987).

According to MCClintock \& PeArse (1987), no taxonomic difference in the composition of the gonad exists, with high levels of protein and lipid being observed in all taxa. It is of interest to note that, in the present study, the lipid levels were higher in the ovaries than in the testes, a result observed in a number of other species (Fenaux et al., 1977; McClintock \& Pearse, 1987; Lawrence \& Byrne, 1994) and in particular in several species of Antarctic Echinodermata (MCCLINTOCK \& PEARSE, 1987).

The lipid levels observed in the gut are relatively high (10.6-27.2\%), and similar to those observed in Echinoidea from polar regions (MCClintock \& PEarse, 1987). These observations reveal the importance of this organ in nutrient storage. Indeed, a number of researchers have demonstrated that the gut is the site of shortterm reserve accumulation (LAWRENCE et al., 1966; LAWRENCE, 1967, 1970; FENAUX et al., 1975, 1977; KLINGER et al., 1988; BISHOP \& WATTS, 1992). Under food limiting conditions, the lipids (in particular the neutral lipids) and carbohydrates are drawn upon to meet the organism's immediate metabolic needs (LAWRENCE, 1970; Fenaux et al., 1975, 1977). Compared to the results obtained in other species, the gut of $P$. lividus seems to contain a relatively high level of carbohydrates (between 3.4 and $12.6 \%$ ). A. lixula alone has carbohydrate levels similar to those of the present study (3.4-10.2\%) (FenauX et al., 1975, 1977). Other species have much lower carbohydrate levels in the gut (between 0.7 and $4.6 \%$ ) (LAWRENCE, 1967, 1970; MCClintoCK et al., 1990a; LAREs \& MCClinToCK, 1991; MCClinTOCK \& Pearse, 1987). The carbohydrate reserves in the gut of $P$. lividus seem therefore to be important.

The biochemical composition of the test is also similar to that of other Echinoidea from various geographic areas. As in the other organs examined, no major difference in test composition was observed between $P$. lividus and sea urchins living at different latitudes or depths (Lawrence \& Guille, 1982; MCClintock \& Pearse, 1987). Most of the test is composed of ash originating from the skeletal matter. The most abundant organic compounds are the soluble and insoluble proteins, while the lipid and carbohydrate levels are low. The high levels of skeletal material point to the structural function of the test (MCCLINTOCK \& PEARSE, 1987). The divergent protein levels in the test of different species are generally due to the proportion of connective tissue present. This tissue helps support the test plates and is rich in protein (MCCLINTOCK et al, 1990a). The energetic levels in P. lividus tests are low $\left(4.3 \mathrm{~kJ} \cdot \mathrm{g}^{-1}\right)$ but comparable to those recorded for other species. Energy level is strongly linked to protein level and, consequently, to the quantity of connective tissue (MCCLINTOCK et al., 1990a). The total energy level of the test is also highly dependent upon its mass. Larger individuals therefore invest a significant amount of total energy here (LAWRENCE \& BYRNE, 1994). As the mass of the test is appreciably greater than that of the other organs, this component represents the main energy containing body part. Even during the reproductive periods, the gonads have a lower energy level than the test. As is true for the gonads and gut, the test is also a nutrient storage organ (LAWRENCE, 1971; FENAUX et al., $1975,1977)$. Under food limiting conditions, test carbohydrates and lipids are used 
almost immediately. FENAUX et al. (1975) and LAWRENCE (1971) demonstrated that protein levels decline during starvation and could excecd losses in carbohydrates and lipids (which indicate tissue destruction). The present study reveals that, in a lagoon environment, even if the lipid and carbohydrate levels in the test of $P$. litidus are low, the nutrient reserves available in this organ are quite important due to protein levels.

Previous studies on biochemical composition variations in the gonad of other species have revealed that gametogenesis is typically characterized by increased protein levels and glycogen storage (GIESE et al., 1959 in FENAux et al., 1977; MIWA, 1966; Moss \& LAWRL:NCE, 1972; FENAUX et al., 1977). In the case of proteins, this result is confirmed for $P$. lividus: levels were significantly correlated to the gonadal index. Lipid levels, however, differ from species to species and can either increase and then diminish (Miwa, 1966; Gifse ef al., 1959 in Fenaux et al., 1977), or they can remain constant (Moss \& Lawrence, 1972). According to Fenaux et al. (1977), the period of carbohydrate and lipid level increases corresponds to an accumulation of reserves which are subsequently used during gamete development. In $P$. lividus carbohydrates decrease from January to June. This period corresponds, according to histological studies of this species in the Mediterranean, to the last part of the maturation period and to the spawning period (GUETTAF, 1997). Carbohydrate level variations in $P$. litidus are close to those reported in FENAuX el al., (1977).

Very little data, however, are available on variations in the biochemical composition of the gut in Echinoidea. Moss \& LAWRENCE (1972) observed low carbohydrate variations (accompanied by low levels) and an erratic variability of the protein levels in Mellita quinquiesperforata (LESKE) (now Mellita tenuis, according to Harold \& Telford, 1990). Conversely, Fenaux et al. (1977) observed steady protein levels and a temporally staggered storage of carbohydrates and lipids in $A$. lixula. This staggered storage of nutrients could be due either to a different food type, or to the transformation of sugars and lipids in order to build up energy reserves for gonad maturation. LAWRENCE \& LANE (1982) suggested that the gut was probably not an important source of nutrients for gametogenesis due to its small mass compared to the gonad. The present study reveals no evident link between the reproductive cycle and the variations in the lipid and carbohydrate levels in the gut. A fall and spring decrease in the carbohydrate gut level was observed during the two annual spawns, however, as was a halt in lipid level increases starting in March (during the spring spawn as well). The relationship between the temporal evolution of the biochemical composition and the repletion index cycle (Fig. 3) is also not very clear. Indeed, the lipid levels (which indicate nutrient storage) increase during winter, a time in which the repletion index reaches its lowest yearly value, but remain constant once feeding has resumed. A comparison between these variations and the sea urchins' trophic activities seems necessary if we are to understand the observed biochemical fluctuations. Indeed. the quality and quantity of food ingested can influence the biochemical composition of the gut. Finally, the variations observed for the test are low and irregular for all the compounds cxamined. They seem to be linked neither to the reproductive cycle nor to the repletion index cycle.

In conclusion, the biochemical variability in $P$. lividus from a lagoon environment is similar to that observed in other sea urchin species living in the open sea. 
Although coastal lagoons are considered to be unstable environments in terms of ecological factors, with important environmental fluctuations during the year (e.g., temperature, oxygen) (KIENER, 1978), this habitat does not seem to affect either the biochemical composition or the metabolic processes and nutrient allocation in the different organs. $P$. litidus is an important member of the benthic community in the Urbinu lagoon (De Casabianca et al., 1973). Its density typically varies from 0.2 to 27 indiv. ${ }^{*} \mathrm{~m}^{-2}$ (depending on the benthic communities present and on bottom type) and can be as high as 120 indiv. ' $\mathrm{m}^{-2}$ in numerous sites (FERNANDEZ, 1990). The P. lisidus stock in this lagoon was estimated at approximately 6 million individuals (FERNANDEZ, 1990). The high energy content of an adult $P$. lividus ( 80 kJ) makes this echinoid an important store of materials and energy within this and other lagoonal environments along the coast of France.

\section{Summary}

The gonads and the gut of Paracentrotus lividus living in a lagoon environment contain a high level of protein (both soluble and insoluble); lipids are also relatively abundant while carbohydrate levels are low. The test is mostly composed of ash and the most abundant organic compounds are the soluble and insoluble proteins, while the lipid and carbohydrate levels are low in this body part. Seasonal changes in the biochemical composition of tissues secm to be linked to the reproductive cycle for the gonads and both to the reproductive cycle and the sea urchin's trophic activity for the gut. No evident relationship between seasonal changes in the biochemical composition of the test and the physiological cycles was observed.

\section{Acknowledgements}

The author wishes to thank Prof. C. F. Boulrourisque and Prol. J. M. Lawrexce for their comments on earlier drafts of this manuscript. We also thank $L$. BRonzzrs of Caraffa, manager of the SCORSA. for allowing us to work in the Urbinu lagoon and for making facilities at sea available. We would also like to thank Prol. D. Viat.F, of the University of Corsicil, for the interest that she has shown in our research.

\section{References}

BARNFS, H. \& J. BLACKSTOCK, 1973: Estimation of lipids in animal tissucs: detailed investigation of sulfovanillin methods for total lipids. J. Exp. Mar. Biol. Ecol., 12: 103-113.

Bishop, C. D. \& S. A. WATTs. 1992: Biochemical and morphometric study of growth in the stomach and intestine of the echinoid Lyed himms aricgans (Echinodermata). Mar. Biol. 114: 459-467.

Brody, S. 1945: Biocnergetics and growth. Hafner Publ. Co. Inc.. New York; 1023 pp.

De Casabianca, M. L. A. Kiener \& 11. Huve, 1973: Biotopes et biocénoses des étangs saumâtres corses: Biguglia, Diana, Urbino. Palo. Vic Miliew, 23 (2): 187227.

Dubois, M. K. A. Gilles, J. K. Hamilton, P. A. Rfber \& F. Smith, 1956: Colorimetric method for determination of sugar and related substance. Anal Chem., 28: 350-356.

Fenaux. L., G. Malara, C. Chllakio, R. Charra \& 1. Palaz7oli, 1977: Evolution des constituants biochimiques des principaux compartiments de l'outsin Arbacia lixula (L.) au cours dun cycle sexucl et des effets d'un jeûne de courtc durée au cours de la maturation sexuelle. J. Exp. Mar. Biol. Ecol, 28: 17-30. 
--, G. Malaka \& R. Charra, 1975: Effet d'un jeune de courte durée sur les principaux constituants biochimiques de l"oursin Arbacia lixula. I. Stade de repos sexuel. Mar. Biol, 30: 239 244.

Fernandez, C., 1990: Recherches préliminaries à la mise en place d'un pilote d'aquaculture de l'oursin Paracentrofus litidus dans un étang corse. Mém. D. E. A. Océanologie, Univ. Aix-Marseille II; 61 pp.

-, 1996: Croissance et nutrition de Paracentrotus lividus dans le cadre d'un projet aquacole avec alimentation artificielle. These Doct., Univ, Corse, Corte; 279 pp.

-- \& C. F. Boudouresoue, 1997: Phenotypic plasticity of Paracentrotus lividus (Echinoidea: Echinodermata) in a lagoonal environment. Mar. Ecol, Prog. Ser., 152: 145-154.

\& A. Caltagirone, 1994: Growth rate of adult Paracentrotus lividus in a lagoon environment: the effeet of different diet types. In: B. David, A. Gulle, J. P. FÉral \& M. Roux (Eds.), Echinoderms through time. Balkema Publ., Rotterdam: 655-660.

..., E. Dombrowski \& A. Caltagirone, 1995: Gonadic growth of adult sea urchin Paracentrotus lividus (Echinodermata: Echinoidea) in rearing: the effect of different diet type. In: R. EMson, A. Smith \& A. Camprei.. (Eds.). Echinoderms Research 1995. Balkema Publ., Rotterdam: 269-275.

Floreto, E. A. T. S. Teshima \& M. Ishikawa, 1996: The effects of seaweed diets on the growth, lipid and fatty acids of juveniles of the white sea urchin Tripneustes gratilla. Fish. Sci., 62(4): $589-593$

GLLse, A. C., 1966a: On the biochemical constitution of some Echinoderms. In; R. A. Boolotian (Ed.), Physiology of Echinodermata. John Wiley, New York: 757-796.

,-- 1966 b: Lipids in the economy of marine invertebrate. Physiol. Rev., 46: 244 298.

Guettaf, M., 1977: Contribution à l'étude de la variabilité du cycle de reproduction (indices gonadiques et histologie des gonades) chez Paracentrotus lividus (Echinodermata : Echinoidea) en Méditerranée Sud Occidentale (Algérie). These Doct. Univ, Méditerranée, Marseille; $132 \mathrm{pp}$.

Grosjean, P. \& M. JaNGOUX, 1994: Effect of light on feeding in cultivated echinoids (Paracentrotus Iividus). In; B. David, A. Gullle, J. P. FÉRAL \& M. Roux (Eds.), Echinoderms through time. Balkema Publ., Rolterdam: 691.

Harold, A. S. \& M. Tflford, 1990: Systematics, phylogeny and biogeography of the genus Mellita (Echinoidea: Clypeateroidea). J. Nat. Hist., 24: 987-1026.

Kiener, A., 1978: Ecologie, Physiologie et economie des eaux saumâtres. Masson Ed., Paris; $220 \mathrm{pp}$.

Klinger, T. S., S. A. Watts \& D. Forcucci, 1988: Effect on short term feeding and starvation on storage and synthetic capacities of gut tissues of Lytechinus variegatus (LAMArCK) (Echinodermata : Echinoidea). J. Exp. Mar. Biol. Ecol., 117: 187-195.

LARES, M. T. \& J. B. MCCLNTOCK, $199 \mathrm{t}$ : The effect of food quality and temperature on the nutrition of the carnivorous sea urchin Eucidaris tribuloides (Lamarck). J. Exp. Mar. Biol. Ecol., 149: 279 286.

LAWRENCE, J. M., 1967: Lipids reserves in the gut of three species of tropical sea urchins. Caribb. J. Sci., $7(1-2): 65-68$.

- 1970: The effect of starvation on the lipid and carbohydrate levels of the gut of the tropical sea urchin Echinometra mathaei (BLA INviL..E). Pac. Sci., 24(4): 487-489.

,-- 1971 : Effect of starvation on the organic nutrient reserves in the test of Tripnewstes gratila (L.) (Echinodermata : Echinoidea) from the gulf of Elat. Isr. J. Zool., 20: 249-251.

--, 1973: Level content, and caloric equivalents of the lipid, carbohydrate, and protein in the body components of Luidia clathrata (Echinodermata : Asteroidea : Platyasterida) in Tampa Bay. J. Exp. Mar. Biol. Ecol., 11: $263-274$.

,-- 1975 : On the relationships between marine plants and sea-urchins. Oceanogr. Mar. Biol. Annu. Rev, 13: 213-286

--\& M. BYRNE, 1994: Allocation of resources to body components in Heliocidaris erythrogramma and Heliocidaris tuberculata (Echinodermata : Echinoidea). Zool. Sci. Japan, 11: 133-137.

-- \& A. Guillf, 1982: Organic composition of tropical, polar and temperate-water echinoderms. Comp. Biochem. Physiol., 72B(2): 283-287

\& J. KarRI, 1979: Number, biomass, and caloric content of the echinoderm fauna of the rocky shores of Barbados, Mar. Biol., 52: 87-91.

- \& J, M, LANF, 1982: The utilisation of nutrients by post metamorphic echinoderms. In: M. JANGOUX \& J. M. LAwrence (Eds.), Echinoderm nutrition. Balkema Publ., Rotterdam: 331-371.

-- A. L. LAWRENCE \& A. C. GifsF, 1966: Role of the gut as a nutrient-storage organ in the purple seaurchin (Strongylocentrotus ptupuratus). Physiol. Zool, 39(4): 281-290.

\& P. W. SAmmarco, 1982: Effect of feeding on the environment : Echinoidea. In: M. JANGOUX \& J. M. Lawrence (Eds.), Echinoderm nutrition. Balkema Publ., Rotterdam: 499-519.

Le Dirfac'H, J. P., 1987: La pêche des oursins en Méditerranée: historique, technique, législation, production. In: C. F. Bounouresoue (Ed.), Colloque international sur Paracentrofus linidus et les oursins comestibles. GIS Posidonie, Marseille: 335-362.

Le Gall, P., 1989: Echinoculture In: G. BArnabe (Ed.), Aquaculture, Vol. 1 (2éme édit). Lavoisier Tech \& Doc, Paris: 468-49l.

\& D. Bucaille, 1987: Intérêt d’un élevage intensif de l'oursin violet Paracentrotus lividus. In: C. F. 
Boudourlsque (Ed.), Colloque international sur Paracentrotus fividus et les oursins comestibles. GIS Posidonic, Marseille: 399-405.

Lowry, O. H.. J. N. Rosebrough, A. L. Farr \& R. J. Randal., 1951; Protein measurement with folin reagent. J. Biol. Chem., 193: 265-275.

MCClistock J. B., J. L. Cameron \& C. M. Young, 1990a: Biochemical and energetic composition of bathyal echinoids and an asteroid, holothuroid and crinoid from the Bahamas. Mar. Biol., 105: $175-183$.

--, T. Hopkins, S. A. WATTS \& K. Marion, 1990b: The biochemical composition of somatic body components of echinoderms from the northern Gulf of Mexico. Comp. Biochem. Physiol. 95A(4): $529-532$.

-- \& J. S. PEarse, 1987: Biochemical composition of antarctic echinoderms. Comp. Biochem. Physiol, 86B(4): $683-687$

Mlller, R. J. \& K. H. MaNN. 1973: Ecological energetics of seaweeds zone in a marine bay on the Atlantic coast of Canada. III. Energy transformation by sea urchins. Mar. Biol., 18; 99-114.

Mrwı, K., 1966: Biochemical studies on sea urchin. 1- Variation of nutrients stock in a sea urchin gonad processing in the maturity. Bull. Hokkaido Reg. Fish. Res. Lab., 31: 73-88.

Moss, J. E. \& J. M. LawrFNCE, 1972: Changes in carbohydrates, lipids and proteins levels with age and season in the sand dollar Mellita quinquiesperforata. J. Exp. Mar. Biol. Ecol., 8: 225-239.

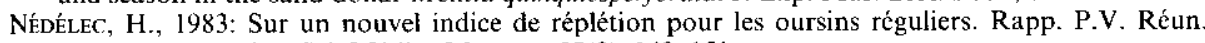
Cormm. Int. Explor. Sci. Médit., Monaco, 28(3): 149--151.

Stbutet, M. \& J. M. LaWrFNCE, 1981: Organic content and biomass of abyssal holothuroids (Echinodermata) from the Bay of Biscay. Mar. Biol., 65: 143-147.

Traer, K., 1980: The consumption of Posidonia oceanica Delile by echinoids at the isle of Ischia. In: M. Jangoux (Ed.), Echinoderm: Present and past. Balkema Publ., Rotterdam: 241-244.

VerlaquF, M., 1987: Relations entre Paracentrotus lividus (LMk.) et le phytobenthos de Méditerranée occidentaje. In: C. F. Boubouresouf (Ed.), Colloque international sur Paracentrotus lividus et les oursins comestibles. GIS Posidonie, Marsielle: $5-36$.

Zar, J. H., 1984: Biostatistical analysis. Prentice Hall International Ed.. New York; 718 pp. 